\title{
PENGARUH HABBATUSSAUDA (NIGELLA SATIVA) TERHADAP VIABILITAS BAKTERI PROTEUS MIRABILIS PADA LUKA KAKI DIABETIK SECARA IN VITRO
}

\author{
Alifia Ayu Delima ${ }^{1}$, Saharuddin² \\ ${ }^{l}$ Departemen Mikrobiologi, Program Studi Pendidikan Dokter, UIN Alauddin Makassar \\ ${ }^{2}$ Departemen Anatomi, Program Studi Pendidikan Dokter, UIN Alauddin Makassar
}

Email: ${ }^{1}$ alifia.ayu@uin-alauddin.ac.id

\begin{abstract}
Abstrak
Luka kaki diabetik merupakan salah satu komplikasi utama pada penyakit diabetes mellitus. Jika ulkus dibiarkan tanpa penatalaksanaan yang baik akan mengakibatkan infeksi atau gangrene. Habbatusauda (nigella sativa) memiliki efek antimikroba, antiinflamasi, dan antidiabetik. Penelitian ini bertujuan untuk mengetahui pengaruh habbatussauda terhadap viabilitas bakteri Proteus mirabilis pada luka kaki diabetik. Penelitian ini dilakukan secara in vitro pada isolat luka kaki diabetik yang berasal dari 15 sampel. Uji antimikroba dilakukan dengan inokulasi pada media PCA (Plate Count Agar), medium MSA (Manitol Salt Agar), dan uji daya hambat dilakukan dengan pengukuran diameter tiap jenis cakram. Hasil penelitian menunjukkan bahwa jumlah koloni bakteri proteus mirabilis tertinggi pada sampel ialah sebanyak $3 \times 10^{12}$ dengan diameter daya hambat habbatusauda terkecil yaitu $14 \mathrm{~mm}^{2}$. Kesimpulan dari penelitian ini adalah terdapat asosiasi yang bermakna antara diameter daya hambat habbatussauda terhadap pertumbuhan koloni bakteri Proteus mirabilis.
\end{abstract}

Kata kunci: luka kaki diabetik, diabetes melitus, habbatusauda, proteus mirabilis.

\section{Pendahuluan}

Salah satu komplikasi penyakit diabetes melitus yang utama adalah Luka Kaki Diabetik (LKD). Secara global prevalensi LKD ditemukan $6.3 \%$ dengan prevalensi tertinggi di Belgia 16.6\%, dan terendah di Australia $1.5 \%{ }^{1}$. Di Indonesia dilaporkan kejadian LKD sekitar $12 \%$ dan resiko LKD sekitar $55.4 \%^{2}$. LKD dapat mengalami infeksi (Diabetic foot infection/DFI) dimana sekitar $44-68 \%$ pasien LKD yang dirawat di Rumah Sakit mengalami Diabetic Foot Osteomyelitis (DFO) yang berujung pada terjadinya amputasi pada tungkai bawah. ${ }^{3}$

Mikroorganisme $>1 \times 106$ /gram jaringan pada luka dianggap infeksi ${ }^{4}$. Mikroba pada luka kaki diabetik dapat bersifat monomikroba dan polymikroba. Penelitian yang dilakukan oleh Tiwari et al menemukan bahwa $43.5 \%$ infeksi monomikroba dan $35.5 \%$ infeksi polymikroba dengan bakteri yang dominan adalah bakteri gram negatif (-) salah satunya adalah Proteus mirabilis. ${ }^{5}$

Melihat angka kejadian diatas, maka diperlukan suatu alternatif untuk mengurangi angka kejadian LKD tanpa menimbulkan resistensi terhadap antibiotik. Salah satu pengobatan yang sering dilakukan adalah pengobatan konvensional.

Berbagai penelitian telah memperlihatkan efek habbatussauda (nigella sativa) sebagai analgesik, antipiretik, antihipertensi, bronkodilator, berpotensi meningkatkan sistem kekebalan tubuh, antioksidan, antitumor dan antidiabetik. Penelitian tentang habbatussauda juga menunjukkan adanya potensi sebagai antibakteri. Aktivitas antimikroba habbatussauda disebabkan oleh komponen utamanya yaitu tannin, tymoquinon, thymol, a-pinene, p-cymene 
dengan cara menghambat pembentukan asam nukleat (RNA) dan sintesis protein. Tymoquinon sebagai komponen utama dapat menyebabkan tidak aktifnya protein bakteri dengan membentuk kompleks irreversible dengan asam amino nukleofilik sehingga protein kehilangan fungsinya serta meniadakan substrat bagi mikroorganisme. ${ }^{6}$

\section{Bahan dan Metode}

Penelitian ini dilakukan secara in vitro di Laboratorium RS Unhas selama 3 minggu. Populasi sampel ialah pasien luka kaki diabetik. Sampel penelitian yang digunakan adalah isolat koloni bakteri dari pasien luka kaki diabetik yang bersedia mengikuti penelitian dan menandatangani informed concent, dan terdaftar sebagai pasien ulkus kaki diabetik yang rawat inap dan rawat jalan di RS Unhas. Adapun alat dan bahan yang digunakan ialah Habbatussauda yang dalam bentuk minyak jintan hitam asal Syiria dengan merk dagang G, isolat luka kaki diabetik, Blood Agar / Agar Darah Domba (ADD), media PCA (Plate Count Agar), effendor, inkubator $37^{\circ} \mathrm{C}$, sentrifus, medium (Nutrient Agar), MCA (MacConkey Agar), medium TSI (Triple Sugar Iron), SIM (Sulfida Indole Motility), citrate urea, kovacks, medium MSA (Manitol Salt Agar), dan katalase $\left(\mathrm{H}_{2} \mathrm{O}_{2}\right)$. Prosedur penelitian diawali dengan persiapan habbatussauda, lalu dilakukan inokulasi bakteri, uji antimikroba, dan uji daya hambat.

Parameter yang diamati pada penelitian ini adalah jumlah koloni bakteri Proteus mirabilis pada isolat luka kaki diabetik dan uji daya hambatnya terhadap habbatussauda. Data yang diperoleh disajikan dalam bentuk tabulasi dan narasi.

\section{Hasil Penelitian}

Penelitian ini dilakukan secara in vitro yaitu suatu metode uji pada media buatan, yang sesuai dengan lingkungan optimal yang diperlukan mikroba untuk hidup. Penelitian ini menguji daya hambat yang dihasilkan oleh habbatusauda terhadap bakteri yang ditemukan pada ulkus kaki diabetik. Zona hambat yang terbentuk diukur dengan satuan mm. Hasil yang ditemukan berupa jumlah koloni bakteri dan diameter daya hambat habbatusauda pada sampel dengan bakteri dominan Proteus mirabilis.

Tabel 1 menunjukkan bahwa koloni bakteri Gram negatif yang dominan ditemukan pada luka kaki diabetik adalah Proteus Mirabilis yaitu 6 responden (40\%), sedangkan Gram Positif Staphylococcus haemolyticus sebanyak 5 responden $(33,4 \%)$.

Tabel 1. Karakteristik Bakteri dominan pada sampel

\begin{tabular}{lllc}
\hline Bakteri Dominan & Golongan & $\mathrm{n}$ & $\%$ \\
\hline $\begin{array}{l}\text { Staphylococcus } \\
\text { haemolyticus }\end{array}$ & Gram & 5 & 33,4 \\
$\begin{array}{l}\text { Staphylococcus } \\
\text { aureus }\end{array}$ & $\begin{array}{l}\text { Gram } \\
\text { positif }\end{array}$ & 2 & 13,3 \\
$\begin{array}{l}\text { Proteus Mirabilis } \\
\text { Gram } \\
\text { negatif }\end{array}$ & 6 & 40 \\
$\begin{array}{l}\text { Grametobacter } \\
\text { baumanii }\end{array}$ & $\begin{array}{l}\text { Gram } \\
\text { negatif }\end{array}$ & 2 & 13,3 \\
\hline
\end{tabular}

Berdasarkan tabel 2, jumlah koloni Proteus mirabilis tertinggi yaitu pada sampel AY.11 yaitu sebanyak $3 \times 10^{12}$, sedangkan jumlah koloni terendah didapatkan pada sampel AY.10 dimana jumlah koloni bakteri 
nya sebanyak $4 \times 10^{10}$. Mean diameter daya hambat habbatusauda tertinggi terhadap bakteri Proteus mirabilis pada sampel penelitian ini adalah $22,5 \mathrm{~mm}$, yaitu kode sampel AY.10 sedangkan terendah diperoleh pada kode sampel AY.11 yaitu $14 \mathrm{~mm}$ dapat dilihat pada Gambar 1.

Tabel 2. Diameter daya hambat habbatusaudah pada sampel dengan bakteri dominan Proteus mirabilis

\begin{tabular}{ccc}
\hline $\begin{array}{c}\text { Kode } \\
\text { Sampel }\end{array}$ & $\begin{array}{c}\text { Jumlah } \\
\text { Koloni }\end{array}$ & $\begin{array}{c}\text { Diameter daya } \\
\text { hambat } \\
\text { Habbatusaudah } \\
\text { (Mean+SD/mm) }\end{array}$ \\
\hline AY.7 & $29 \times$ & \\
& $10^{10}$ & 21 \\
AY.8 & $18 \times$ & 21 \\
& $10^{10}$ & 21 \\
AY.9 & $8 \times 10^{10}$ & 22,5 \\
AY.10 & $4 \times 10^{10}$ & 14 \\
AY.11 & $3 \times 10^{12}$ & 15 \\
AY.12 & $11 \times$ & $10^{10}$ \\
\end{tabular}

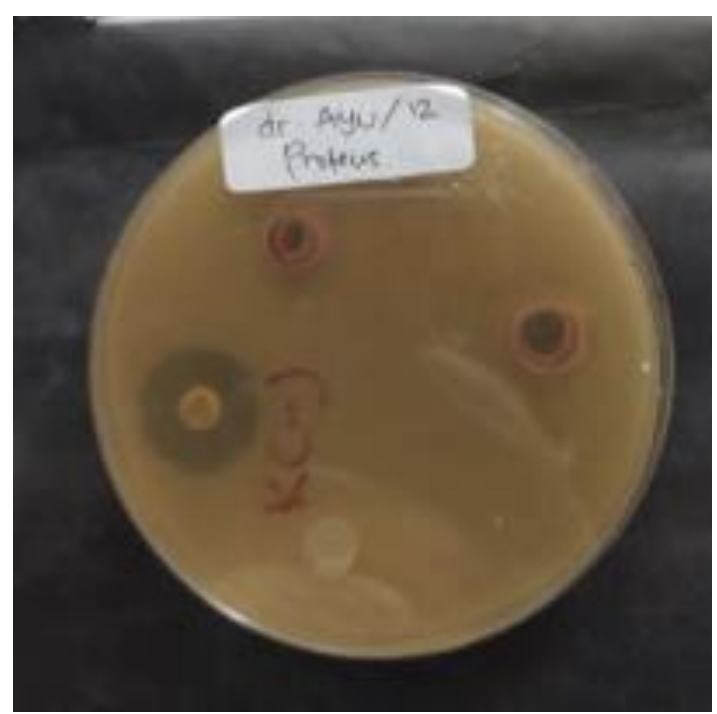

Gambar 1. Hasil uji daya hambat habbatusauda terhadap bakteri Proteus mirabilis

\section{Pembahasan}

Salah satu penyebab terjadinya luka kaki diabetik adalah infeksi. Infeksi dapat dibagi menjadi tiga yaitu superfisial dan lokal, selulitis dan osteomyelitis. Infeksi akut pada penderita yang belum mendapatkan antibiotik biasanya monomikrobial sedangkan pasien dengan ulkus kronis, gangrene dan osteomyelitis bersifat polimikrobial.

Karakteristik bakteri pada luka kaki diabetik didapatkan bahwa bakteri Proteus mirabilis yaitu bakteri Gram negatif yang paling banyak ditemukan. Hal tersebut sesuai dengan penelitian yang dilakukan oleh Saltoglu et al yangjuga menunjukkan bahwa bakteri garam negatif paling banyak menyebabkan infeksi kaki diabetik $(54.8 \%){ }^{7}$ Namun, Penelitian ini tidak sejalan dengan penelitian yang dilakukan Jockenhöfer et al (bahwa bakteri gram negatif (-) yang dominan adalah Pseudomonas Aeruginosa (31.1\%). ${ }^{8}$

Terlihat kecenderungan bahwa semakin tinggi koloni bakteri Proteus mirabilis, maka diameter daya hambat habbatusauda yang terbentuk semakin sempit. Keadaan ini bisa saja terjadi karena kemampuan habbatusauda sebagai antimikroba bekerja lebih ekstra ketika menghadapi jumlah koloni yang lebih besar, sehingga diameter daya hambat yang terbentuk bisa saja jauh lebih sempit dibanding ketika menghadapi jumlah koloni yang lebih kecil. Pola ini juga terbaca pada empat sampel lainnya. Pola yang sedikit berbeda ditemukan pada sampel AY.12 dimana jika mengacu pada pola yang lain, maka seharusnya diameter daya hambat yang terbentuk tidak jauh berbeda daripada jumlah koloni AY.7, AY.8, dan AY.9. 
Penelitian ini telah membuktikan bahwa habbatussauda (Nigella sativa) merupakan salah satu pengobatan islam yang sering digunakan sebagai antimikroba. Rasulullah SAW bersabda "Tetaplah kamu berobat dengan habbatussauda, karena sesungguhnya ia mengandung bahan penyembuh bagi setiap penyakit kecuali mati" (Hadist Al Bukhori) ${ }^{9}$. Perlu dilakukan penelitian lebih lanjut untuk membandingkan antara habbatusaudah dengan antibiotik, atau senyawa lainnya untuk melihat efek antimikrobial dan efek anti inflamasi khususnya pada pasien dengan luka kaki diabetik.

\section{Simpulan}

Terdapat asosiasi yang bermakna antara diameter daya hambat habbatussauda terhadap pertumbuhan koloni bakteri Proteus mirabilis.

\section{Daftar Pustaka}

1. Zhang, P., Lu, J., Jing, Y., Tang, S., Zhu, D., \& Bi, Y. (2016). Annals of Medicine Global epidemiology of diabetic foot ulceration: a systematic review and meta-analysis. Annals of Medicine.

2. Yusuf, S., Okuwa, M., Irwan, M., Rassa, S., Laitung, B., Thalib, A., Sugama, J. (2016). Prevalence and risk factor of diabetic foot ulcer in a regional hospital, Eastern Indonesia. Open Journal of Nursing, 6 (January), 1-10.

3. Asten, S. A. V. Van, Fontaine, J. La, Peters, E. J. G., Bhavan, K., \& Kim, P. J. (2016). The microbiome of diabetic foot osteomyelitis. Eur J Clin Microbiol Infect Dis, 35, 293-298.

4. Baranoski, S., \& Ayello, E. (2012). Wound Care Essentials; Practice Principles (Third Edit). Philadelphia.
New York: Lippincott William \& Wilkins.

5. Tiwari, P., Kumar, B., Kaur, M., Kaur G. \& Kaur H., 2011, Phytochemical Screening and Extraction: A Review, International Pharmaceutica Sciencia, 1 (1), 98-106.

6. Raisa adhiba dkk. 2009. Obat kumur jintan hitam (nigella sativa) 17,5\% terhadap penurunan gingivitis. Surabaya. FKG Unair.

7. Saltoglu N, Yemisen M, Ergonul O et al (2015) Predictors for limb loss among patient with diabetic foot infections: An observational retrospective multicentric study in Turkey. Clin Microbiol Infect 21(7): 659-64

8. Jockenhöfer, Gollnick, Herberger, Isbary, Renner, Stücker, Dissemond. (2013). Bacteriological pathogen spectrum of chronic leg ulcers: Results of a multicenter trial in dermatologic wound care centers differentiated by regions.

9. Hadits Al-Bukhari no. 5688/Al-Fath X/143, dan Muslim no. 2215 dari Abu Hurairah Radhiyallahuanhu. Lafazh ini adalah lafazh Muslim. 